\title{
Spiritual senses as a resource ${ }^{1}$
}

\author{
ANNA HAAPALAINEN \\ University of Turku
}

\begin{abstract}
This article discusses knowledge gained through experiencing the presence of God through the 'spiritual senses' as a resource in an Evangelical Lutheran parish. Believers' being-in-touch experiences with the divine produce a special kind of knowledge that can be shared and passed on in the parish. This 'spiritual asset' plays an important part in parochial activities. This development can be explained by the rise of experience-based religiosity and charismatic Christianity, a global Christian trend which is also affecting the mainline churches.

Keywords: Christianity, Evangelical Lutheranism, charisma, spirituality, senses, knowledge
\end{abstract}

A: [B] ut if there is a permanent change, it is always from God. I really yearn for the way God changes people. It is always a great miracle when you are there to see it. You really cannot say that the whole church is like 'Wow, wow! What happened?' But anyway, it is a miracle.

Q: How do you see it?

A: You just see it.

Q: But how?

A: It's like... You see it with your spirit. You just can't say that it happened now, or now he believes this sentence or something like that, like he is doing this or that. You just see it like [snaps fingers] and that is when the inner motivation has rotated 180 degrees and everything is seen with new eyes. (Interview 1.)

This short extract is from an interview I conducted in 2012. I was talking with a chaplain of the Michael's Parish² (Turku, Finland), and we were discussing the work they were doing in the parish. During the interview he

1 This article was supported by the Church Research Institute and Oskar Öflunds Stiftelse.

2 The Michael's Parish prefers to use the translations 'Michael's Parish and Michael's Church' without the prefix 'St' mainly because the Finnish names are Mikaelinseurakunta and Mikaelinkirkko without the prefix 'saint' (pyhän). The parish and the church are named after the Archangel Michael. 
emphasised that the church (the Evangelical Lutheran Church of Finland ${ }^{3}$ ) had not 'cared about people', and that they were trying to change that attitude in their own parish. He talked about the importance of lay activity, and how they were encouraging laypeople to be involved in constructing a 'living parish'. From his perspective the key method for increasing lay involvement was to promote the work of the Holy Spirit in granting 'spiritual gifts'. During the interview he talked about growing in faith, making a personal choice, receiving a spiritual baptism, and interacting with God, Jesus, and the Holy Spirit as an integral part of everyday religiosity. In his parish 'spiritual senses' ${ }^{4}$ were in active use as an important resource for reinforcing lay agency and thus strengthening the role of experience-based religiosity in the wider church.

The traditional forms of Finnish Evangelical Lutheranism, which is often described as a folk church, have been strongly based on teaching and word. There is a perception that this traditional form of Evangelical Lutheranism fails to provide sufficient room for individual experience and emotion which emphasise ways of expressing personal spirituality or sharing knowledge about God gained through the 'spiritual senses'. Recently, however, more sensual forms of Evangelical Lutheranism have emerged, especially in city parishes. (Haapalainen 2015, 104; Palmu et al. 2012; Interviews 1-5.) I argue that an experience-based knowledge of the transcendent has become a more visible and public feature of Finnish Evangelical Lutheranism, and that the diminishing value of church-based religiosity is causing church bodies to identify forms of religious practice which enable active lay involvement and emphasise the importance of experience-based religiosity in parishes especially in larger cities.

The 'spiritual senses' are treated in this article as the capacity to be-intouch with the transcendent. This sensing of the 'other' (see Utriainen 2016) is indeed an embodied practice in which the bodies of believers come to be defined by their ability to affect and be affected (Blackman 2012). Although a resource for individual believers, the spiritual senses are also something which - from the institution's perspective - needs controlling. This article's approach considers the role of the social group in the process of 'embodied

3 Henceforward I will use acronym ELCF when referring to the Evangelical Lutheran Church of Finland.

4 Paul L. Gavrilyuk and Sarah Coakley (2012) speak about this spiritual sensitivity of beingin-touch with the 'other' through the notion of 'spiritual senses' particularly from historical and theological viewpoint. Their usage of the notion of 'spiritual senses' resonates with the emicunderstanding of these being-in-touch experiences arising from my ethnographic materials. 
pedagogy' (Utriainen 2016). This notion refers to the processes in which believers are taught ways to 'feel the presence' and 'testify about their experiences of being touched by the Spirit' (cf. Brahinsky 2012; de Witte $2009 ; 2011$ ). However, the social direction, enforcing, or constructing of the correct way to feel the Spirit is only one side of the coin. The other is that by adapting and using the 'spiritual senses' laypeople gain a more substantial agency and religious expertise among their peers, as well as among parish workers. The value placed on lay religiosity has the potential to transform Finnish Evangelical Lutheranism.

This article is based on ethnographic fieldwork I conducted between 2012 and 2014 at the Michael's Evangelical Lutheran Parish. ${ }^{5}$ I use interviews with the parish's workers and field notes from various parish events. ${ }^{6}$ I also use supporting textual materials, such as strategies published by the ELCF. The article's theoretical discussion is based on three examples, each related to a different kind of event, drawn from my fieldwork material. The first is a compilation from various small group discussions held after Bible study, the second is a description of a service held in the parish hall, and the third description is from a weekend event. The first two descriptions are mainly of activities organised by the parish and its workers, but the last was a collaborative event held with the support of an organisation called 'Spiritual Renewal in Our Church' (SROC). ${ }^{7}$ In all these cases the embodied experiences of encountering God, lay activity, and lay agency are strongly emphasised, albeit in slightly different ways. Before I present these ethnographical descriptions, I will examine the context that has enabled these forms of experience-based religiosity to emerge alongside traditional Finnish Evangelical Lutheranism more closely.

5 The Michael's Parish is in the southern coastal town of Turku, Finland. It belongs to the Turku and Kaarina Parish Union (Evangelical Lutheran Church of Finland). The parish itself extends from the city centre to Turku's port and includes several large suburbs. The parish is diverse and the socioeconomic status of people living within its boundaries varies greatly. Some suburbs struggle with problems of unemployment and marginalisation, but there are also upper middleclass and middleclass socioeconomic pockets. The parish's core operations and events happen in the church itself, in the central parish house, the church hall, or the surrounding area. (FN2011; FN2012).

6 The interview and field note material are anonymised. However, it should be acknowledged that anonymisation is never waterproof and there is a possibility that subjects may be recognised. I have therefore chosen to use interviews with workers rather than with parishioners, because workers have been interviewed as office holders in the organisation, and therefore have a more secured position than parishioners. I have kept the ethnographical descriptions somewhat general to avoid giving information that might lead to individual laypeople in the Michael's Parish being recognised.

7 Henceforward SROC. For more information about Spiritual Renewal in Our Church, see Haapalainen 2015, 101. 


\section{Why spiritual senses? The ELCF's problem and answer}

The decline in institutional forms of religion does not mean that religion itself has somehow lost its relevance in people's lives (Casanova 1994). The reported changes in religiosity during the twenty-first century are thought to have emerged from a twofold process where simultaneously people's affiliation to institutionalised denominations has been in decline and interest in personal spirituality has been increasing (Gillant-Ray 2005, 358). This development has been reported by several scholars of religion (Davie 1994; 2000; 2004; Day 2009; 2010; Heelas and Woodhead 2007; Woodhead 2009). The shifting focus from a church-based religiosity to an individualised spirituality has also affected institutionalised denominations. In ELCF parishes this has meant a process where individual experiences, affects, and personalised faith are emphasised, resulting in increased value being given to lay activities and voluntary work (Kääriäinen et al. 2005, 261; 2003; OCSC 2007; CoE 2015). The ELCF bodies consider involvement in parish life to be more than sitting in the pews and hearing the word at Sunday Mass.

In the Michael's Parish the workers are striving to answer this call for an individualised spirituality. One of the pastors said during an interview: 'Religiosity has moved in a more individualistic direction. It has fragmented into a billion different things and people choose one piece here and one piece there and build their own.' This 'choosing of one's path' clearly poses a challenge for the church. The pastor went on to state that they (the church/ the parish/the pastors) had previously emphasised theological teaching above everything else, but that strategy no longer worked because 'people do not want to be passive and just listen, they want to be involved and do things' (Interview 2). The problem is not merely about the individual's need to construct a personal religious and/or spiritual world, but also their need to be part of and contribute to a group or meaning, even for a short period before turning to something new. Terhi Utriainen $(2016,149)$ writes concerning this tendency:

The concrete and material practices of 'my own path' would allow people to connect the modern value of individual choice with another kind of value: that is, the feeling of being part of something larger, a plan or script that helps one to direct one's own life.

This quotation also aptly describes the attitudes of ELCF workers. As one pastor said to me: 'Yes it [individualisation] is a reality, but it does not exclude the longing for communality.' (Interview 3) ELCF workers believe 
that the 'church' will provide this 'larger plan or script' and within it the individual may find their path. It should also be noted that communality has become fluid and adaptable; forms of participating, contributing, and believing change because of a person's lifestyle, situation, and interests (Frisk \& Nynäs 2012). Thus, the ELCF values lay agency, since it engages people more deeply in parish life. In many interviews and discussions workers shared their concern about the lack of commitment among parishioners. They told me that people did not wish to be part of the parish as a whole, but to 'shop' for events or simply 'pop in' briefly (Interviews 1, 2, and 4). At the same time, ELCF workers agree that theological teaching and guidance has become more demanding because of personalised expressions and practices of faith. In one interview a pastor spoke of how individuals have increasingly wished to add various personalised elements to the sacraments (Interview 2). In another, one of the chaplains said:

And people believe (laughs), and it makes me laugh... people believe anything. Something they read in magazines or see on television [...] I have noticed this especially during the Alpha course. I have encountered these searchers. Many are interested in New Age angels [...] and people with 'healing hands' and all these things that come out of the New Age scene. (Interview 1.)

Influences from a syncretistic and diverse religious environment are treated with derision and discussed in detail, especially New Age influences like those the pastor described. These influences are vigorously uprooted when they are met. Church workers consider angels and healing to belong to the sphere of Evangelical Lutheran theology, and so they reject them when they emanate from another religious or spiritual reality. Workers and parishioners, especially those belonging to the parish's more charismatic sub-groups, agree that the 'spirit world' exists and should be treated with extreme caution.

The challenge of 'individualisation' is a shared one, whether it is caused by internal or external factors, but attitudes about the actions needed to solve this problem vary. The ELCF has launched two 'missional guidelines' (strategies), 'Our Church - Shared Commonwealth' (OCSC 2007) and 'A Church of Encounter' (CoE 2015). Both emphasise individuality and the diminishing value of church-based religiosity as the core problems in the contemporary religious environment; and both present spirituality, emotionality, encounter, lay activity, and experience-based religiosity as key to 
solving the problems the ELCF is facing. In following the very open-ended guidelines presented in the strategies, all the workers at the Michael's Parish emphasise that enhancing the opportunities for lay involvement in the parish is the best way to stop unwanted change. However, the parish's workers propose varying theological solutions to provide a suitable structure to enforce the church's role in people's everyday lives: returning to traditional Evangelical Lutheranism; returning to the fold of 'Mother Church', ${ }^{8}$ or moving in a more charismatic direction (Haapalainen 2015).

Charismatic Christianity has gained a stronger foothold and greater influence in the global Christian arena, especially in recent years. It is flexible and adapts itself to various temporal and spatial contexts. Shared denominators in this 'fluid and flexible' Christian trend are emphasis on a personal faith, individuality, experience-based spirituality, and charisma (Robbins 2010, 156-58; Woodhead 2008, 327; Anderson 2004, 1-15; Ahonen 2003, 129-35; Walker 2000; Bebbington 2000). Neo-charismatic Christianity especially is seen as a product of modernity, a counterbalance to secularisation (Iqtidar and Lehmann 2012, 2, 4). Where the 'spiritual senses' in the Evangelical Lutheran Church of Finland are concerned, it should be noted that the experience of encounter with the transcendent has often been the preserve of the ELCF's revival movements (Anderson 2014, 95; Heikkinen and Heikkilä 1997, 152f; Huotari 1981, 172). From a historical, but also a contemporary, ${ }^{9}$ perspective the ELCF's workers and members supporting more traditional and commonly shared expressions of faith have largely ignored or even rejected the charismatic revivals (Mantsinen 2014, 19, 23; Ruohomäki 2014, 447-50; Salonen et al. 2000, 279; Heino 1997, 61). This rejection of charismatic religiosity in the ELCF belongs to a long continuum in Catholic and Protestant denominations' attitudes towards Pentecostal movements and charismatic Christianity beyond Finnish society (Synan 2001). However, in recent decades charismatic Evangelical Lutheranism has become more visible in the ELCF. This development owes much to the

8 The scenario of a possible return to 'Mother Church' - the Catholic Church for the speaker arose during a rather mundane conversation in the corridor before a parish event. The worker said that if Lutheranism was a lifeboat when the mother ship was adrift, it may now be the case that the lifeboat is no longer needed and that Evangelical Lutherans can return to the fold of the Catholic Church. This short discussion was speculation for the sake of it, but the speaker drew strongly on a more Catholic interpretation of faith in general during our other discussions. (FN2013.)

9 For example, the Nokia Mission was considered to controvert Evangelical Lutheran theology and it was discharged from the ELCF (Puumala 2007; Pihkala 2000). 
work of SROC, ${ }^{10}$ which has resulted in cooperation between SROC and the ELCF from the grassroots to the administrative level, of which the work done at the Michael's Parish is an excellent example (Haapalainen 2015).

Significant numbers of parish workers are ready to admit that charismatic Christianity seems to provide everything that has been lacking in institutionalised - even bureaucratic - church-based Evangelical Lutheranism: a sense of meaning; deep spirituality; sensual experience; and respect for lay involvement in contributing to the parish's spiritual life. One chaplain said this represents a narrow view of charismatic Christianity. He emphasised that 'spiritual gifts ... belong to different parts of the body so that all of them together form a reasonable spiritual whole' (Interview 1). These shared stories and testimonies allow others to enter a space in which they can sense the presence of God and find value in their own lives, but also contribute to the construction of the parish as the 'body of Christ'. People actively involved in charismatic events at the Michael's often say - and even write in a brochure produced by the parish - that the events are 'shamelessly spiritual'. They feel pride in their work and feel that the active use of the 'spiritual senses' is the best way to direct a 'drifting church' back to its former glory. They feel that the end times are near, and the gifts and religious experiences granted to their congregation come directly from God:

In recent theological teaching there has been a lot of talk - how should I put this? - that now the end times are here, God will pour out the Holy Spirit and parishes will return to the ideal state of the first congregation. (Interview 1.)

Although the charismatic groups at the Michael's Parish are unwilling to admit that charismatic practices in Evangelical Lutheranism should be treated as a functional solution to the problem of individualisation, it cannot be said that others, themselves not drawn to charismatic expressions of faith, do not see this kind of religiosity as a functional solution. It is noteworthy that attitudes towards charismatic Christianity are not unanimous. Some of the workers at the Michael's were quite sceptical, and pointed out that charisma and encouraging people to seek the 'spiritual senses' should be treated with extreme caution, since it has the potential to misdirect people's attention towards 'those who have gifts' instead of towards God and the gospel. One worker explained the emergence of charismatic Evangelical Lutheranism somewhat sceptically:

10 SROC/Mission. 'Tavoitteet ja toiminta' [Goals and operations], webpage maintained by Spiritual Renewal in Our Church, <http://www.hengenuudistus.fi/hengen_uudistus_ kirkossamme/>, accessed 29.5.2015. 
Nowadays people, based on Pietism and [the teachings of] Luther too, are quite individualistic and trying to find their own path. [...] Like, a normal slogan is "Have you found our Lord Jesus Christ as your personal Saviour?" So, you have to come to faith even though you have participated in confirmation school - you still have to find God. [...] Lutheranism is drawing strongly on revival Christianity, Pietism, and Pentecostalism. (Interview 4.)

This individualistic undercurrent is also recognised in the reformers' theological tradition, and thus some parish workers think that Finnish Evangelical Lutheranism, though suffering from the changes in the religious landscape (secularisation, post-secularity, new spirituality), is also imbued with Lutheranism's innate individualism. Interestingly, Luther rejected the Catholic 'theology of glory' (that sinful human beings cannot gain knowledge of God through reason) and emphasised the 'theology of the cross', which holds that a believer strives to know the God revealed by the suffering of the vulnerable Jesus on the cross (Mjaaland 2015, 92f.; Mannermaa 1998). When the believer recognises the suffering of the cross through their senses and heart, they can be-in-touch with God and his word (Deschamp 2015, 211f., 217; Morgan 1998, 66). Knowing God through the 'spiritual senses' comes to be framed as personalised embodied practice. ${ }^{11}$ It is a relationship between the human being and God, the individual and the transcendent. Whether it is a supporter or an opponent of charismatic Evangelical Lutheranism, the main concern holds: what if these 'gifts' and the knowledge gained through the 'spiritual senses' are misused and the individual's glory surpasses that of God?

\section{Making room for the spirit}

\section{Small groups}

In small group discussions the theological direction of the laity was more apparent than in other types of event. The intimate setting of a handful of

11 Luther emphasised preaching as the main mode for transmitting the gospel. Those who believe come to hear the Word. The Word itself, understood as the same as the Word of creation, becomes sensible, audible, and visible in the sermon (Jorgenson 2014, 42f., 47). This means that the hearing of preaching co-constituted by the Word of God invigorates the 'spiritual senses' and enables 'the faithful' to sense the divine. For Luther, the 'spiritual senses' take the 'physical senses' as their starting point, but they do not bypass it. Faith approaches art: it enables us to see 'the whole in a part, and the part in the whole', since the 'heart has eyes that reason does not know' (Jorgenson 2014, 49). 
people sitting around a small table drinking coffee with a pastor created an atmosphere in which gentle and deeply personal guidance was easily given. In this 'therapeutic' environment laypeople were given a voice, and some degree of authority, to form their personal and individualised understanding of Lutheran faith, albeit under ministerial supervision.

The Michael's Parish organised 'Tuesday Bible Study' events on a weekly basis in the spring of 2012 (these meetings are still held today). The one hour Bible Study lecture began at 6 p.m. and was followed by coffee, tea, and snacks. People gathered together to share the evening snack and then divided into smaller groups and scattered throughout the parochial house to find a peaceful place to discuss the evening's teaching. I participated in one of these groups in the spring of 2012. The discussions in the groups were loosely connected with the lecture, but at a more personal level than was the case in the general Q\&A session immediately after it. The experiences and thoughts of the laypeople were reflected on in detail and the pastor, who functioned as an unofficial chair, directed the discussion with questions and theological insights related to the topic. This 'direction' was considered vital by the parish workers, because they felt that laypeople lacked theological knowledge and were thus likely to misinterpret their experiences.

Following the lecture on 'Evil' at one Tuesday Bible Study meeting (28.2.2012), the group discussed the 'spirit world' and Satan at length. Many had experiences of malevolent powers tampering with their lives. The image of Satan was personalised: Satan was described as 'the king of lies', 'wanting us to believe that he is strong', or 'attacking believers'. In some descriptions the presence of malevolent powers was quite sensational. People had felt fear, doubt, and strange sensations that were inexplicable and vanished once they started to pray or read the Bible. In another small group discussion, after a lecture on Joshua and Jesus (10.4.2012), the discussion focused on experiencing the mercy and love of God. People shared their own experiences of 'feeling the guidance' or 'feeling the presence' of God in their lives. They spoke of warmth when they felt the love of God or the spiritual security that came from the experience-based knowledge they had gained during these encounters with the transcendent. They concluded that those who believed were like children: they took the faith in its entirety and made no attempt to explain it rationally. They often said that those who had taken Jesus into their hearts should always strive to sense the omnipresence, love, and mercy of God, but that they were at the same time in danger of being attacked by Satan and his demons, who wanted to possess the believer. Indeed, many of the small group discussions after the Bible Study revolved around the 
'spirit world' and the effects that a variety of spirits had on human beings (FN2012). In an interview one of the pastors spoke about this:

We are totally lost where the spirit world is concerned [...] and do not know how to cope with it [...] What if we hear that two laymen have performed an exorcism which the pastor was incapable of dealing with? His job is to take control of the situation, not to run away and say that they did not teach us to handle these situations in the Theological Faculty. (Interview 1.)

Discussions with parishioners and workers suggested that any spiritual experience might be brought about either by God or the spirit world, and therefore every testimony, meditation, and description of personal experiences was subject to evaluation and doubt. Parishioners did not question the possibility that the believer might 'feel' or 'sense' God or that it was possible to gain a specific knowledge of the transcendent through these experiences. There was, however, a system of 'moderation' in these small group discussions in which theological premises were guarded by parish workers and laypeople were 'taught' theologically sustainable interpretations of their experiences. This direction was crystallised in one entry from my interview material: 'We have to be very clear with laypeople. They do not know what they are dealing with. All that is experienced does not come from God, [...] if we as priests do not guide them into the right path, you know.' (Interview 1.) The stories the parishioners shared were indeed considered important, but the pastors re-expressed and explained these experiences. Theological education and knowledge surpassed experience-based knowledge.

\section{Encounter point service}

The second event differed significantly from the small group discussions. The service was more public, and included some teaching, even if it was done somewhat freely. In this event the pastors acted to some extent as examples of how to share spiritual experiences and communicate in a theologically sound way about encounters with divine powers. Lay involvement was neither public nor verbally shared, because the laity were not given an opportunity to share their own experiences. However, the evening's setting enabled people to be-in-touch with the transcendent. The parochial house became a place where a sense of the presence of God was possible, and parishioners were shown the appropriate ways to be connected with God. 
I participated in an Encounter Point ${ }^{12}$ (Kohtaamispaikka) service ${ }^{13}$ at the Michael's Parish house in February 2012. When I arrived, I was met by a welcoming committee that greeted everyone warmly, especially focusing on those who had not been there before. The chaplain in charge had invited a guest speaker who had been a well-known pastor and healer in the late 1990s. The evening began with praise and contemporary Christian music. This was followed by the story of the chaplain's son, who had been ill. The chaplain had prayed and fasted until his son had been healed. This personal story of healing set the parameters for the rest of the evening. Lively and emotional Christian music performed by the 'house band' was interspersed with a short and humorous drama about a healed car crash victim. Parishioners sang along, praised the Lord, raised their hands, and shouted 'Amen' and 'Hallelujah'.

About halfway through the service the chaplain introduced the guest and conducted a short interview with him. 'Who are you really, and how did you become a healer?' the chaplain asked. The guest told of how he had prayed that his wife's back would heal, and that all her problems had disappeared instantly and his wife had recovered. He said this experience had scared him, but he had started to practise prayer for healing in his parish. He felt that he had been appointed for this task by God. He said that the power of healing came from weakness, because it was weakness that made it possible to act as a mediator for God's powers. The power of God fluctuated; it was not the same in every situation. He described how this power entered the 'prayer world' and was real and tangible. Prayer was simultaneously an adventure and a hazard, because the charismatic prayer-healer was always the target of malevolent spirits. People should never, therefore, become attached to their sensations, but should focus on the powers' source. They should ask, 'Am I or is s/he doing this in the name and the blood of Jesus Christ?' because the 'blood of Jesus' evicted satanic spirits and powers. After the interview the congregation recited a confession and prayed for the healer, who responded by blessing them. The chaplain encouraged people to feel the power of God, free their gifts of the Spirit, and come onto the stage to be prayed for and healed. Two-thirds of the congregants formed a row on the stage and the healer, followed by his assistants, started to

12 I have translated the Finnish name Kohtaamispaikka as Encounter Point following the translation logic of the Finnish Evangelical Lutheran Church. For example, their strategy (2015) is called Kohtaamisen kirkko and its official translation is Church of Encounter.

13 These services follow liturgical guidelines, but there is no communion, and the service is quite free in its structure. 
pray with each one of them individually. His head tilted slightly towards the person standing in front of him, he spoke softly, and at the end of his prayer he touched the person. More than $70 \%$ of those who were prayed for and healed collapsed. Some started to speak in tongues, some simply lay there in silence, and a few started to weep, but there were also people who merely walked away from the stage as if nothing had happened (12.2.2012/ FN2012). The spiritual encounter testimonies at this event were given by two pastors. They gave an example of how to share the knowledge gained through encounter with God, and how to describe an apparently indescribable spiritual embodied experience. They also provided a tool for the moral and ethical evaluation of such experiences, and emphasised that everyone should be aware of their source.

\section{Michael's Winter Days}

The third event differed slightly from the others. Lay involvement played a central role in it. Trusted laypeople were permitted to share the knowledge of God they had gained through the 'spiritual senses'. This supported lay agency communicated to the other parishioners that pastors were not alone in having knowledge about God, but that laypeople could contribute and participate in theological teaching. At this event the strongest value was given to lay and experienced-based knowledge.

The Michael's Winter Days took place over two days, and were organised under the title 'Emerge Holy Spirit'. The teaching focused on spiritual gifts as the constructing power in the parish. The Winter Days had several guest speakers, all giving testimonies about the 'work of the Holy Spirit' in their lives. In his introduction the chaplain told the audience that the idea for this event had come as a revelation during the SROC summer event. The revelation had not been 'hindered by the bishops', and the chaplain said that 'they would evangelise using the word of God as it is', and that 'the kingdom of God was and would be revealed' to them. The chaplain continued by saying that there was similar 'charge' in the atmosphere on this occasion and that the Holy Spirit would surely emerge for every participant. As he concluded, he said that it was not important 'to feel in the head [mind] as the Sadducees had, but to feel in the heart', and continued in a raised voice: 'Do you wish to see Him today?' The congregants responded by shouting back 'Yes!'

The first speaker was an Evangelical Lutheran pastor who had struggled with his faith. His first encounter with the Holy Spirit had happened during 
confirmation camp, when the Spirit had touched him so powerfully that he had collapsed between the pews. He had received a mission to act as a shepherd, but he had resisted it for years until the moment of his ordination, when he had had an experience of spiritual baptism. He told the congregation that after the second 'touch of the Spirit' he had collapsed on many occasions. Another speaker spoke of the difficulties she had had in her life. She had been ill, had overcompensated in every area of her life, and had been misguided in her faith until the moment the Spirit had descended on her. At that moment she had had a revelation: 'It was not me, but the Lord in me.' This experience had made her weep for three days in a row, and then she had begun to sing. She said that it was physically impossible to sing after crying for so long, but she had done it anyway and this was a true miracle of God. She had come to know God's phone number, 5015 (Psalm 50:15), and had been given the sense of God's omnipresence in her life. At the end of her talk she showed a PowerPoint slide on which the sentence 'BASIC INSTRUCTIONS BEFORE LEAVING EARTH = BIBLE' was written. She said that the Holy Spirit gave human beings the 'eyes that reveal the true meaning of the Bible'; the basic instructions were in the Bible, but we needed to receive 'the eyes of the heart' to see them.

The evening of the second day of this event was reserved for prayer and praise. It started with a testimony given by one of the Michael's parishioners. He spoke vividly of how he had been touched by the Spirit during one of the chaplain's sermons and how he had shivered and received the gifts of 'contrition and penitence'. After the first testimony another speaker came onto the stage and introduced herself as an 'intercessor, prophet, and God's fool' and began to tell her story. She had been a seeker, trying to find an answer from various religions until the moment she had heard God's voice saying, 'Are you looking for glory for yourself or are you looking for the glory of God?' She said that in that moment an unbearable brightness had surrounded her and she had sensed lightning going through her body. 'The Holy Spirit had touched me,' she said. She had received in that moment a spiritual gift called the 'words of knowledge'.

She continued her testimony by inviting the participants to bring forward their troubles and receive their personal messages from God. She told them: 'Jesus sees you, Jesus heals you.' The 'charge' in the hall increased, praise began, and the congregation began to move around, hands raised, singing, and shouting 'Hallelujah'. The prophet continued, walking around and occasionally stopping in front of someone and telling them what God wanted to say to them. At the end of the evening the prophet shared 'the words of 
knowledge', but now in public so that everyone could hear the prophecies assigned to certain people. She continued for a while and then said: 'Those who want to give their lives to the Lord, come forward. Be courageous. Be brave. I still see people in the pews who have been touched by the Spirit. Come forward.' A group of people gathered on stage and started to pray out loud. The prophet raised her voice and began to pray: 'Father, I am here in front of you. You know my life. You know all the sins that I have committed. I want to give my life unconditionally and wholeheartedly to you!' Participants on the stage and in the pews started to give testimonies, others repeatedly said 'thank you Lord', some wept, and some shivered. The atmosphere was deeply emotional. I sat in the pews and observed the congregation, and some of the pastors present, starting to speak in tongues. The pastor and the laypeople were in that moment all equal in their experiences. (17.-19.3.2012/FN2012.) Pastors and trusted laypeople were permitted to speak during the presentations. After the lay testimonies the chaplain made a few comments about them, framing them with a theological explanation. As representatives of the ELCF institution, the pastors tended to set a certain theological tone in the aftermath of the lay testimonies. However, at the end of the event a free expression of faith was encouraged by both the prophet and the pastors through their own praise, glossolalia, and strong expression of their feelings. The congregation followed their lead.

\section{Two sides of a coin: control and gain}

The Michael's Parish organises various types of event, from highly devotional prayer weekends to family days, and even the declaration of Christmas peace to beloved pets. Clearly, the range of the events has to be wide enough to serve the interests of the parishioners' altering tastes and needs. ${ }^{14}$ The parish's main concern is the decline in its membership, or, to be more precise, the decline in active parishioners who feel that the Michael's Parish is their 'spiritual home'. The interpretation of religiosity supported in the Michael's Parish is to a degree 'vernacular' (Primiano 2012, 1995): lay religiosity is treated as a resource, but with constraints, as has been seen in the example of small group discussions. Moreover, religiosity is indeed seen in the congregation as a practice that penetrates every aspect of people's daily lives. The parish workers see the 'church' and the congregation as theologically supportive structures that enable lay involvement and lay

14 Phenomenon also reported by Palmu et al., 2012, and by the ELFC's strategies OCSC 2007 and CE 2015. 
agency, as well as providing theological teaching and guidance. Teaching and guidance were present in every example, but in various ways: personalised (small groups) and exemplary (Encounter Point, pastors/Winter Days, laypeople). The idea of 'lived religion' - as Meredith McGuire (2008; 1992) has described it - permeates this religious institution and its congregations as active laypeople become increasingly influential in the parish. Nevertheless, it is the institutional framework that has the power to direct the variety of individualised forms of religiosity. In various interviews and discussions parish workers state quite forcefully that parishioners need to 'do' things. One of the deacons told me that it was better to invite people to build a grill shed in the parochial house's yard than it was to invite them to hear the gospel, because when people are 'doing things, it is easier to connect with them because they feel there is a value in their contribution'. Although the deacon was talking about concrete activity with a material result, it is possible to stretch this idea to cover somewhat less tangible activities in which lay involvement is targeted at spiritual construction rather than the construction of a shed. (Interview 5.)

The changing religious landscape in Finland has led the ELCF to scrutinise both its internal and external influences (Palmu et al. 2012). The tables have turned, and the practice of sensing the other have come to the fore not only in the sphere of post-secular spirituality or on the fringes of the ELCF, but in the public religious practice of this highly institutionalised denomination (see: Nynäs et al. 2015). The $\operatorname{OCSC}(2007,39)$ strategy states: 'We support the birth of small operational groups and communities and support the various opportunities whereby the members (of the church) may be able to develop activities and create new forms of operation.' The need for small group activities is recognised by both the institution (the ELCF) and its local parish workers. The institution encourages parishes to organise activities that give room for parishioners' experiences and thoughts, as well as to increase lay involvement, not only as an audience, target group, or listeners, but also as a generative force developing new forms of activity. All the events described are the result of this administrative guideline. Small group discussions are especially seen as the first stage in developing an active and appreciated resource for parishes. They are something that might be called a grassroots embodied spiritual pedagogy (Utriainen 2016), where a combination of respect, guidance, and the value placed on personal experiences enforces parishioners' engagement. The small group discussions are treated as 'safe spaces' where people have an opportunity to reflect on their own life paths or think about the theology connected with them. One pastor described the importance of small group discussions as follows: 
People have that existing need. I think it is good that we have these small groups. In a larger group many just keep their mouths shut; when [they are] in a smaller group they find it easier to ask their questions and say what they are wondering about. (Interview 3.)

However, despite the positive attitude towards increasing lay involvement, there remain some problems. It all comes down to who has sufficient theological education and knowledge, as well as the relationship between laypeople and clergy. For example, it was the pastors who set the tone of the Encounter Point service. However, lay agency was not totally subservient to theological expertise. The free, emotional, and sensational atmosphere of the evening allowed individuals to feel connected with God - to be touched by him. It is noteworthy that the parish also needs to provide the opportunities for people to be encouraged to 'practise' and 'try out' their 'spiritual senses' in an environment that is still theologically constrained.

Religion, and Protestantism especially, in contemporary Western societies is described as 'a sphere of life cut off from bodies, senses and everyday agency'(Utriainen 2016, 148). However, alterities, the variety of others or the transcendent, have found their way back into people's lives through different practices of enchantment, whether these are Christian or not (Ibid.). These religious (enchanted) practices are not merely a way to reclaim religious agency, but are also a means to teach embodied subjects to communicate (contact/construct relationships) with the 'other'. These practices are often built through bodies (Brahinsky 2012; de Witte 2009, 2011; Asad 1993; Mahmood 2005), and thus imprinted in bodies and habitus (Utriainen 2016, 142f). The relationship between a believer and the other (God, Jesus, Holy Spirit) is a practice of enchantment. Being-in-touch with or 'to be touched' by the Spirit translates into language that has its starting point in the physical sensory spectrum, but stretches its limits. It moves to the sphere in which experiences are indeed verbalised differently: 'It seems that the intellect operates in a non-ordinary, indeed unique, way when God becomes the object of its vision' (Gavrilyuk \& Coakley 2012, 6f).

Ways to pass on one's experiences are not explicitly taught, but modes and nuances in the testimonies become familiar through repetition in various small group discussions, meetings, events, and situations, as seen in the examples from my fieldwork at the Michael's Parish. The parishioners, guest speakers, and pastors are all contributors to and subjects of what Terhi Utriainen $(2016,143)$ calls 'embodied pedagogy'. To reach out, to contact, and to form and sense a relationship with the other is the first step. Taking 
this first step was encouraged in small group discussions and especially in the Encounter Point service. The second step is taken when these experiences are passed on. At the Michael's Winter Days trusted laypeople were given the stage. Many had a long history of giving testimonies. They were people who had started at the grassroots level and had gradually gained a stronger foothold in the sphere of the public teaching of theology, not quite as pastors' peers, but close enough.

All these activities aim to enable the 'communication of transcendence' (Besecke 2005) within an institutionalised religion. The ELCF workers and representatives have realised that religion, following David Morgan (2010, 8 ), does not 'happen in spaces and performances but as them'. It is the people who practise religion, who choose to participate or to step aside. The intensity of emotions and sensational experiences increasingly defines the ways people 'live their religion' or practise it in Western societies (Taira 2006, 19, 46-51). The parochial hierarchies between clergy and laypeople still draw strongly on theological education and knowledge, but the knowledge gained through the 'spiritual senses' is now more valued. Charismatic practices especially - made possible by smaller charismatic communities inside the parish - provide 'enchanted', intense, and emotional experiences that enforce believers' individual relationships with God. These charismatic Evangelical Lutheran communities are built systematically within the larger communities where the congregation or the whole church acts as the body.

As has already been said, this tradition of sensing the transcendent has always belonged to Finnish Evangelical Lutheranism: it can even be found in the writings of Luther himself. It is not, therefore, something novel or extraordinary. However, this experience-based, emotional, and sensational religiosity is more prominent than it has previously been. Its increasing influence means that the relationship between parish workers and parishioners is changing. Parish workers no longer organise events for laypeople or act as dispensers of theological knowledge, but accompany laypeople in sharing their experiences. Such testimonies, meditations, and descriptions of being touched by the Spirit cannot be ignored. In the Michael's Parish expertise based on experience is flourishing under the guidance of theological experts. Moreover, the gospel is not to be shared by the church workers (deacons, youth workers, pastors, chaplains, or the vicar) alone with laypeople, but also between laypeople:

When we talk about missionary work or evangelisation, then it is definitely from person to person. [...] For example, let's take the message 'God loves 
you'. To see it printed in a newspaper is one thing, but when another person says it to you, it is a stronger message. (Interview 2.)

At the heart of these practices are the bodies of believers, because encountering the transcendent is understood as first and foremost a sensory experience, though one that is profoundly different than other sensory experiences. Because it is extraordinary it must be directed by the parish's workers. This embodied knowledge is a valued resource in the parish because it sends a powerful message to parishioners that their religious experience is almost as valuable as theological teaching, or at least as something that adds value to the more traditional forms of Finnish Evangelical Lutheran religious life.

References

Fieldnotes

FN2011 Author's fieldnotes, 2011, personal archives.

FN2012 Author's fieldnotes, 2012, personal archives.

FN2013 Author's fieldnotes, 2013, personal archives.

\section{Interviews}

\section{Interview 1}

The Michael's Parish worker interview. Conducted by author, 30th November 2012.

Interview 2

The Michael's Parish worker interview. Conducted by author, 12th September 2013.

Interview 3

The Michael's Parish worker interview. Conducted by author, 3rd July 2013.

Interview 4

The Michael's Parish worker interview. Conducted by author, 14th May 2013.

\section{Interview 5}

The Michael's Parish worker interview. Conducted by author, 20th November 2012. 
The Evangelical Lutheran Church of Finland Strategies

CoE

2015 A Church of Encounter (Kohtaamisen kirkko), website maintained by the Evangelical Lutheran Church of Finland, <http://sakasti.evl. / OCSC sakasti.nsf/ sp?open\&cid=Content2656A1>, accessed 25.9.2015.

2007 Our Church: shared commonwealth (Meidän kirkko. Osallisuuden yhteisö.) Suomen kirkon strategiaa vuoteen 2015 laatineen työryhmän mietintö. Suomen evankelisluterilaisen kirkon keskushallinto, Sarja C 2007:10 (Helsinki, Kirkkohallitus), website maintained by the Evangelical Lutheran Church of Finland, <http://sakasti.evl. /sakasti. nsf/0/9297F603 C875C1C8C225770A002E3448/\$FILE/kirkon_strategia_2015_mietinto.pdf $>$, accessed 29.5.2015.

Bibliography

Ahonen, Risto A.

2003 Karismaattinen ja evankelikaalinen hengellisyys. - Seppo Häyrynen, Heikki Kotila \& Osmo Vatanen (eds), Spiritualiteetin käsikirja, 129-50. Helsinki: Kirjapaja.

\section{Anderson, Allan Heaton}

2014 An Introduction to Pentecostalism: Global Charismatic Christianity, 2nd edn. Cambridge: Cambridge University Press.

\section{Asad, Talal}

1993 Remarks on the Anthropology of the Body. - Sarah Coakley (ed.), Religion and the Body, 42-51. Cambridge: Cambridge University Press.

Bebbington, D. W.

2000 Evankelikalismi. - Modernin Teologian Ensyklopedia, Finnish translation editorial board Pauli Annala, Petri Järveläinen \& Antti Saarelma. Helsinki: Kirjapaja.

\section{Besecke, Kelly}

2005 Seeing Invisible Religion: Religion as Societal Conversation about Transcendent Meaning. - Stef Aupers \& Dick Houtman (eds), Religions of Modernity. Relocating the Sacred to the Self and the Digital, 89-114. Leiden \& Boston: Brill.

\section{Blackman, Lisa}

2012 Immaterial Bodies: Affect, Embodiment, Mediation. London: Sage.

\section{Brahinsky, Josh}

2012 Pentecostal Body Logics: Cultivating a Modern Sensorium. - Cultural Anthropology 27(2), 215-38. 


\section{Casanova, José}

1994 Public Religions in the Modern World. Chicago: University of Chicago Press.

\section{Davie, Grace}

1994 Religion in Britain since 1945: Believing without Belonging. Oxford: Blackwell.

2000 Religion in Modern Europe: A Memory Mutates. Oxford: Oxford University Press.

2002 Europe, the Exceptional Case: Parameters of Faith in the Modern World. Darton, Longman and Todd.

Davie, Grace \& Paul Heelas \& Linda Woodhead

2003 Predicting Religion: Christian, Secular and Alternative Futures. Aldershot: Ashgate.

Day, Abby

2009 Believing in Belonging: An Ethnography of Young People's Constructions of Belief. - Culture and Religion 10(3), 263-78.

2010 Propositions and Performativity: Relocating Belief to the Social. Culture and Religion 11(1), 9-30.

\section{Deschamp, Marion}

2015 An Embodied Theology. Body Images and the Imagination of God by Luther. - Anne Eusterschulte \& Hannah Wälzholz (ed.), Anthropological Reformations - Anthropology in the Era of Reformation, 209-28. Göttingen: Vandenhoeck \& Ruprecht.

Frisk, Liselotte \& Peter Nynäs

2012 Characteristics of Contemporary Religious Change: Globlization, Neoliberalism, and Interpretative Tendencies. - Peter Nynäs \& Mika Lassander \& Terhi Utriainen (eds), Post-secular Society, 47-70. New Brunswick: Transaction Publishers.

\section{Gavrilyuk, Paul L. \& Sarah Coakley}

2012 The Spiritual Senses: Perceiving God in Western Christianity. New York: Cambridge UP.

\section{Gilliat-Ray, Sophie}

2005 'Sacralizing' Sacred Space in Public Institutions: A Case Study of the Prayer Space at the Millennium Dome. - Journal of Contemporary Religion 20(3), 357-72.

\section{Haapalainen, Anna}

2015 An Emerging Trend of Charismatic Religiosity in the Evangelical Lutheran Church of Finland. - Approaching Religion 5(1), 98-113.

\section{Heelas, Paul \& Linda Woodhead}

2007 The Spiritual Revolution: Why Religion is Giving Way to Spirituality. Oxford: Blackwell Publishing. 


\section{Heininen, Simo \& Markku Heikkilä}

1997 Suomen kirkkohistoria. Helsinki: Edita.

\section{Heino, Harri}

1997 Mihin Suomi tänään uskoo. Porvoo: WSOY.

\section{Huotari, Voitto}

1981 Kirkkomme herätysliikkeet tänään. Helsinki: Kirjapaja.

\section{Jorgenson, Allen}

2014 Martin Luther on Preaching Christ Present. - International Journal Of Systematic Theology 16 (1), 42-55.

\section{Kääriäinen, Kimmo \& Kati Niemelä \& Kimmo Ketola}

2003 Modernikirkkokansa. Suomalaisten uskonnollisuus uudella vuosituhannella. Tampere: Kirkon tutkimuskeskuksen julkaisuja, 82.

2005 Religion in Finland: Decline, Change and Transformation of Finnish Religiosity. Tampere: Church Research Institute Publications, 54.

\section{Luther, Martin}

1961 Sermons on St. John. Helmut T. Lehmann (ed.), Luther's Works, vol. 24. Missouri: Concordia Publishing House.

\section{Mahmood, Saba}

2005 Politics of Piety: The Islamic Revival and the Feminist Subject. Princeton: Princeton University Press.

\section{Mannermaa, Tuomo}

1998 Why Is Luther So Fascinating? Modern Finnish Luther Research. Carl E. Braaten \& Robert W. Jenson (eds), Union with Christ: The New Finnish Interpretation of Luther, 1-20. Grand Rapids: Eerdmans.

\section{Mantsinen, Teemu T.}

2014 Helluntalaiset luokkakuvassa. Uskontokulttuuri ja yksilön luokka-asemaa Turun Helluntaiseurakunnassa. Turku: Annales Universitatis Turkuensis, C387.

\section{McGuire, Meredith B.}

2008 Lived Religion: Faith and Practice in Everyday Life. Oxford: Oxford University Press.

1992 Religion: The Social Context. Belmont: Wadsworth.

\section{Mjaaland, Marius Timman}

2015 The Hidden God: Luther, Philosophy, and Political Theology. Bloomington: Indiana University Press.

\section{Morgan, David}

2010 Introduction. The Matter of Belief. - David Morgan (ed.), Religion and Material Culture: The Matter of Belief, 1-18. London \& New York: Routledge. 


\section{Nynäs, Peter, Ruth Illman \& Tuomas Martikainen (eds)}

2015 On the outskirts of 'the Church': Diversities, Fluidities and New Spaces in Contemporary Religion. Berlin-Münster-Wien-Zürich-London: LITVerlag.

Palmu, Harri, Hanna Salomäki, Kimmo Ketola \& Kati Niemelä

2012 Haastettu kirkko. Tampere: Kirkon tutkimuskeskuksen julkaisuja, 115.

Pihkala, Juha

2000 Epätervettä karismaattisuutta. Aamulehti, 31.12.2000.

Primiano, Leonard Norman

2012 Afterword: Manifestations of the Religious Vernacular: Ambiguity, Power, and Creativity. - Marion Bowman \& Ülo Valk (eds), Vernacular Religion in Everyday Life. Expressions of Belief, 382-394. London: Equinox.

1995 Vernacular Religion and the Search for Method in Religious Folklife. - Western Folklore 54(1), 37-56.

\section{Puumala, Anne}

2007 Harhaoppinen. Savon Sanomat, 13.5.2007.

\section{Robbins, Joel}

2010 Anthropology of Religion. - Allan Anderson, Michael Bergunder, André Droogers \& Cornelis van der Laan (eds), Studying Global Pentecostalism: Theories and Methods, 156-78. Berkeley: University of California Press.

\section{Salonen, Kari \& Kimmo Kääriäinen \& Kati Niemelä}

2000 Kirkko uudelle vuosituhannelle, Suomen evankelis-luterilainen kirkko vuosina 1996-1999. Tampere: Kirkon tutkimuskeskus.

\section{Synan, Vinson}

2001 Streams of Renewal at the End of the Century. - Vinson Synan (ed.), The Century of the Holy Spirit: 100 Years of Pentecostal and Charismatic Renewal, 1901-2001, 349-80. Nashville: Thomas Nelson.

\section{Taira, Teemu}

2006 Notkea uskonto. Turku: Eetos.

\section{Utriainen, Terhi}

2016 Doing Things with Angels: Agency, Alterity and Practices of Enchantment. - Riku Hämäläinen, Heikki Pesonen \& Terhi Utriainen (eds), Helsinki Study of Religions: A Reader, 138-51. Helsinki: Helsingin yliopisto.

Walker, Andrew

2000 Helluntailaisuus ja karismaattinen kristillisyys. Modernin Teolo- 
gian Ensyklopedia, Finnish translation editorial board P. Annala, P. Järveläinen, and A. Saarelma. Helsinki: Kirjapaja.

\section{de Witte, Marleen}

2009 Modes of Binding, Moments of Bonding. Mediating Divine Touch in Ghanaian Pentecostalism and Traditionalism. - Birgit Meyer (ed.), Aesthetic Formations. Media, Religion and the Senses, 183-205. New York: Palgrave MacMillan.

2011 Touch. - Material Religion 7(2), 148-55.

\section{Woodhead, Linda}

2009 Christianity. - Linda Woodhead, Hiroko Kawanami \& Christopher Partridge (eds), Religions in the Modern World: Traditions and Transformations, 2nd edn. London: Routledge. 
